\title{
A BRIEF INTRODUCTION TO ALLAMA MUHAMMAD IQBAL'S POLITICAL PHILOSOPHY
}

\author{
Abdul Qayum Khan \\ Lecturer, Kohat University of Science and Technology, Khyber Pakhtunkhwa, Pakistan. \\ qayumkhan2006@hotmail.com \\ Nadeem Ahmad \\ PhD Scholar, Department of Anthropology, Quaid I Azam University, Islamabad, Pakistan. \\ nadeem.takkar4@gmail.com
}

\begin{abstract}
In Iqbal's political philosophy and practice, parliamentary spiritual democratic system is universalistic and particularistic in its range. Global in nature, it is anchored in the religion of Islam that gives it a universal look. In 1926, when he entered politics to realize this ideal in practice, his ideas started to reflect the political scenario of the subcontinent. Besides Islam, Iqbal had made use of a good deal of western political concepts of nationalism, democracy, secularism, sovereignty, ethics of politics and communism. But he neither fully appreciates nor discards out rightly all these concepts. On the other hand, he has expounded his own political ideals of Tauhid, Khudi, Marde Momin, Islamic democracy, Millat, etc. Through these patterns of thought, Iqbal try to train an individual, a society and a global Islamic order. This universal order as it is construed from the concept of ummah will strive for the promotion of pan-humanism, i.e., freedom, brotherhood, and equality of humanity. In this paper Iqbal's political philosophy, his concept of Khudi, how he perceives an ideal society will be analyzed. It will also be highlight that how his political philosophy changed from one stage to another.
\end{abstract}

Keywords: Allama Iqbal, Political Philosophy, Muslim Society in India, Islam, Nation-State

\section{INTRODUCTION}

Muhammed Iqbal (1877-1938) is a national poet of Pakistan. He is equally famous and well-known in India and beyond for his philosophical, poetic, and political works and services that he rendered for Pakistan, India, Afghanistan, Iran, and the Muslim world at large. The political objective condition of subcontinent in pre-partition time influenced his poetry and politics in marked way. These political conditions ranged from British and Indian rivalry to the Muslim/ non-Muslim or Muslim League and Congress rivalry. Iqbal in his poetry and practices has eloquently given expression to these conditions. Not only expressed it, but he also delivered speeches, addresses, and wrote about the amicable solutions of all these problems in the best interest of all. This paper attempts to highlights that how Iqbal thought did evolve with respect to the Indian political situation as well as how far his thought is innovative and/or influenced from others.

Methodologically, this research analyses the political philosophy within the historical context of subcontinent. The data for this paper was collected from different published sources including books and research papers on Iqbal, his poetry and philosophy. Poetry couplets for the paper are taken from different papers and books on Iqbal and from poetry collections of Iqbal including Bang e Dara and Ramuz e Bekhudi which are quoted with each couplet in the paper. Furthermore, the collected data is analyzed through thematic analysis where themes were developed in the collected data. In the process of thematic analysis all the collected data went through line-by-line coding in the first step. In the next step the data was organized and put under certain themes which helped in making argument from the data. The method of thematic analysis was helpful in developing themes, connectivity of themes and making sense and argument from the themes.

\section{Evolution in Iqbal Philosophy}

The political philosophy of Allama Muhammad Iqbal (1877-1938) went through several phases of development. The first (until 1905) was pan-Indian nationalism with a belief in the nationhood based on language, culture, race, and geography. The second (1905-08) was transitional/mental 
conflict and the third (1908-26) was pan- Islamism/Muslim nationalism advocating political unity of the Muslim world. The fourth (1926-38) was supra- nationalism/internationalism wherein the Muslim ummah was universal, the boundaries of the state were for administrative convenience only and the affinity was spiritual.

Iqbal's poetry and prose, despite their philosophical content and tone, are overtly political. This can be attributed to the political environment of British India in the late nineteenth and in the first half of the twentieth century; any intellectual of that period, whether Hindu or Muslim, could not help but join the struggle for freedom in their respective capacities (Qazi, 2013). He has written many poems reflecting his first state of mind and philosophy i.e., pan-Indian nationalism. For instance, National Song for Hindustani Children takes pride in the beautiful features of the country like the great prophetic traditions, fertile soil, and heritage (Dani, 1977). Similarly, the Tarana-i-Hindi describes Hindustan as a lovely and lovable country; "Thou seest deity in the images of stone / For me there is deity in every particle of the country's dust" (Khattak, 1998) (Iqbal, 2018). According to Riffat Hassan a writer and political analyst: "Two things which stand foremost in Iqbal's pre1905 political poetry is: his desire to see a self-governing and united India free of both alien domination and inner dissension (Hassan D. R., 2008). This thinking of line portrayed the given political situation of India wherein British asserted its state authority against Indian and Indian asserted their identity-based politics against each other. This position denies of him as being 'fanatics', according to Dino and Ahmed (2018). Secondly his constant endeavor to draw attention to those factors of decadence which caused the decline of Muslims in India" (Malik H. , 1971).

Iqbal visited Europe in pursuit of higher education and stayed there for three years, 1905-08. There he underwent a radical change. He became ambivalent towards pan-Indian nationalism and became pan-Islamist therein. He believed that self-centered competition between man and man and between nation and nation disintegrates human society. When he came back from Europe, he had already given up pan- Indian nationalism and adopted the cult of Pan-Islamism: from now onward started believing in one Muslim Ummah. He was no more believing in race and nationality and asked for unity among the Muslims. As he writes, "Break, break the idols of color and race / In the Millat yourself you must efface / Call not yourself of Turkish nationality, or an Irani, or an Afghani (Iqbal, 2018).

Iqbal had now donned the mettle of pan-Islamism by advocating the role of religion in politics. He now believed that "politics has its roots in the spiritual life of man... [and] religion is a force of great importance in the life of individual as well as nations" (Maitre, 1963). The membership of Islam is not determined by birth, locality, or naturalization. The expression 'Indian Mouhammedan,' however convenient it may be, is a contradiction in terms. Since, Islam is the religion which is considered above time and space condition. Muslim's nationality has no geographical basis. The Muslims looks for it in the holy town of Mecca (Sherwani, 1977).

In the beginning Iqbal interest in practical politics remained very low rather he remained critic of Congress and Muslim League policies (Parray, 2013). However, against to his previous conviction, he entered the realm of politics in 1926 where he tried to combine "his Islamic universalism and territorial nationalism..." (Quershi, 1977). "It seems to me that God is slowly bringing home to us the truth that Islam is neither nationalism nor imperialism but a League of Nations which recognizes artificial boundaries and racial distinctions for facility of reference only, and not for restricting the social horizon of its members" (Quershi, 1977) ${ }^{1}$.

\section{Iqbal and Western Ideas of Politics}

After coming from Europe, where he closely observed and interacted with the Western life, Iqbal disapproved of the Western civilization. He discarded nationalism because of its divisive influence in society especially of Muslims.

Zafer Ishaq Ansari writes that Iqbal observed that how "nationalism had destroyed the idea of universal brotherhood; how it had created barriers between man and man and between nation and nation; how it had sown seeds of international discords. Furthermore, he also became conscious of the dangerous possibilities of the idea of nationalism in the context of the Muslim world" (Malik N. S., 1998). Again, the same author writes that "Iqbal's condemnation of nationalism is not a condemnation of love of the fatherland. It is a condemnation of the modern concept of nation and

\footnotetext{
${ }^{1}$ This political phase will be further discussed at the end.
} 
fatherland, the significance of which is not merely geographical. 'It is rather principle of human society' which claim to be the only proper basis of cohesion and unity in human society and which exiles religion from playing a befitting role in human society" (Malik N. S., 1998).

It is this (nationalism) which divides the creatures of God into nations,

It is this which strikes the roots of the nationality of Islam (Ahmad, 1995).

For Iqbal religion was a unifying and central factor to politics and society of ummah (Pay, 2015). As he says, "Our heart is not of India, Turkey and Syria / Our commonplace is nothing but place" (Iqbal, Ramuz-e-Bekhudi, 2010) (Malik N. S., 1998). Iqbal does not believe in the secularism of European political thought. He considers that separation of church and state occurred due to material advancement and nationalism demands from the people to switch over their loyalties from religion to nation-state. K. K. Aziz writes that "one of the things on which Iqbal takes an uncompromising stand is the unique character of Islam as a combination of the spiritual and the worldly. It is as much an ethical system as a polity. It is not a religion in the ordinary sense of the word; it is a way of life".

Islam does not bifurcate the unity of man into an irreconcilable duality of sprit and matter. In Islam God and universe, sprit and matter, church, and state, are organic to each other. Man is not the citizen of a profane world to be renounced in the interest of a world of sprit situated elsewhere. To Islam matter is sprit realizing itself in space and time'. This is said to emphasize the fact that there is no place in Islam for a separation of religion and state, of things spiritual and secular (Aziz, 1987).

Iqbal also discusses positive and negative aspects of communism. Iqbal's condemnation of concentration of wealth in few hands, exploitation of workers by capitalist class, his welfare feeling for the Punjab's peasants and the landlords' unjust treatment of peasants, are having socialistic appeal to the people. He writes few poems in this connection like: 'Punjab Kai Dehqan Sey' (To the Punjab Peasant) and 'Lenin Khudda Kai Hazur Main' (Lenin in the Presence of God) are socialistic in nature. Parveen Feroz Hassan writes that "Iqbal points out that though Marx is not a prophet, he has a book to his credit" (Hassan P. F., 1970). Iqbal appreciates communism for its stand on the equality, principle, labor rights and exploitative economic order of capitalism, but, in the words of Parveen Feroz, it is the 'Godlessness' of the communist doctrine which infuriated Iqbal. "In Javid Nama he advises the Communists to change their attitude of negation of God to positive recognition of the Almighty" (Hassan P. F., 1970). He praises Zakat institution of Islam and the equality of Islam. Iqbal was opposed to capitalism and communism for different reasons.

How Iqbal views western democracy? Dr. Waheed Ishrat has deducted Iqbal's criticism of democracy from his poetry as following:

1. The Western democratic system is the same old European Caesarism or imperialism.

2. The Western democracies only protect the interest of capitalists.

3. He was against the philosophy of one's man one's vote. He believed that majority of the common people cannot be equal to wise man. He was in favor of wise man decision.

4. The democratic institutions such as election, membership, council, and president ship etc are the rotten eggs of the new civilization.

\section{Iqbal Own Innovative Ideas}

Now we would study Iqbal's own innovative ideas that has no western moorings. His assumptions of tauhid (Oneness of God and the prophet hood of Muhammad), khudi (ego), momin (The Perfect Man), millat (The Community, individual and community relationship), and ijtihad (parliamentspiritual democracy) are pivotal to his political philosophy. Tauhid is fundamental to all aspects of life. Writing about the importance of tauhid in politics Iqbal says "that the new culture finds the foundation of world-unity in the principle of tauhid. Islam, as a polity, is only a practical means of making this principle a living factor in the intellectual and emotional life of mankind. It demands loyalty to God, not to thrones. And since God is the ultimate spiritual basis of a life, loyalty to God virtually amounts to man's loyalty to his own ideal nature" (Sheikh, 1989).

For these concepts of khudi, momin, milliat, individual and community relationship, and its significance, Parveen Feroz Hassan's book The Political Philosophy of Iqbal, would be used as a reference unless otherwise mentioned. His books Asrar-i-Khudi and others explain the concept of khudi. Iqbal does not use this term in the meaning of arrogance but rather ego is proportional strength of object. Firmness and determination are its activating virtues that lead man towards 
change, creativity and triumph as famously said for Iqbal by one author "I act, therefore I am". His concept of Khudi is based on Quranic verse, "Verily God will not change the conditions of man till they change what is in themselves". The individual himself takes the initiative in the development of khudi. In Iqbal's words an individual becomes a 'dead matter' if he ceases to know the importance of sprit within him. Ideas alone are not sufficient there must be action, movement, restlessness, love, and courageous sense of the importance of the self. Iqbal writes in the preface of his book which book that "the Quran is the book which emphasizes 'deed' rather than 'idea"" (Sheikh, 1989)

Khudi is continuous struggle in life for the higher mission. Certain qualities are essential for the growth and consolidation of khudi like: ishq (love) faqr (indifference to material possessions), courage and creativity. These qualities make khudi a powerful force. Similarly, some factors also weaken it like fear, beggary, and slavery. As he says, "The light of the self, and the fire of the self / Constitute the very essence of Islam, the fire of the Self nourishes life with enlightenment and consciousness / This is the nature of every object, and this is the cause of growth, however, the Nature has concealed its essence" (Ahmad, 1995).

The concept of momin in Iqbal is also based on the Quran, which is a major inspirational source for his views. His momin is not only an embodiment of all the Quranic principles but is in fact, the Quran in action. The momin has great qualities of power, vision, action, and wisdom. These qualities in their perfect form are most noticeable in the character of Holy prophet. By these qualities when brought into action momin reaches to the stage of perfection and master of universe. Iqbal says that a momin is the replica of Divine qualities. Iqbal's momin is a moral creature, who is endowed with spiritual and religious prowess, and acting within the boundaries of the Canon Law is a mastercreator himself. His ceaseless struggle is directed towards the conquest of the universe and its culmination reaches when God and universe are absorbed in his being. The whole concept is, however, idealistic in nature. When such human emerges, is not clearly given in his thought but the momin will evolve from the inherent potentials and his spiritual and intellectual endeavors. As he says, "Transmute thy handful of dust into gold / Kiss the threshold of the Perfect man" (Faruqi, 1979).

\section{Islam, Individual, Community and State}

This community is bound by the belief of tauhid, and not by the factors of geography and ethnic bonds. He elaborates the same theme in the verses which say that our Master (the Holy Prophet), by leaving his native land resolved the problems of Muslim nationhood. Iqbal's millat is a universal community of Believers, transcending all barriers of caste, color, race, nationality, and territory. This concept of his is linked with the pan-Islamic movement that was going on in subcontinent and other Muslim countries at that time. He advocates like an individual the community must live a life of constant struggle and ceaseless endeavour. He further says that community has also its khudi which has all the attributes of the individual ego. Vigour, force, power, determination, will rise and move forward, and courage to fight, are the characteristics of the collective khudi of the community. He asks the Muslim world to consolidate the khudi as it was done by the Turks and Egyptian for their development, because without it state and religion cannot exist.

After discussing these concepts separately, Iqbal then establishes a relationship between the individual and community. He says that the community is a great blessing for the individual who provides ample opportunities to the development of his heart and head. Similarly, community gets organization and strength from the individual. He connects khudi (self), self here means an individual, and bekhudi (selflessness), here means community. If self-inculcates uniqueness, initiative, determination and ambition, selflessness creates a spirit of sacrifice, devotion, and merger of the individual wills into the bigger will of the community for the greater good of all the members of community.

The individual exists as a part of society. Alone he is nothing

A wave is a wave only inside the river

Outside of it, it is nothing (Ahmad, 1995).

Now, how Iqbal conceives democracy in Islam and Muslim world? Iqbal criticism of western democracy was mainly due to the peculiar circumstances that Muslim were facing either in the Subcontinent or elsewhere, but he was not outright rejecter of this value. His political thought is akin to democratic government in the individual Islamic state or democracy-based Islamic an 
international order. He terms his democracy as a "spiritual democracy", different in many respects from Western democracy. "Let the Muslim of today appreciate his position, reconstruct his social life in the light of ultimate principles, and evolve, out of hitherto partially revealed purpose of Islam, that spiritual democracy which is the ultimate aim of Islam" (Sheikh, 1989). Parveen Feroz writes that "Iqbal condemns the Western democracy and advocates in its place the spiritual democracy. In fact, the spiritual democracy is the only form of government that suits the ideological state of Iqbal". Thus, Iqbal's belief is that Islamic political system which is democratic in nature, and rests on spiritualism' (Hassan P. F., 1970). The same author has noted down the following political principles that Iqbal considered that have a democratic essence.

1. Election was the only way to express the will of the people, and partial expression of people's will be considered null and void.

2. De facto political sovereignty resided with the people.

3. The caliph was not necessarily the high priest of Islam. He was not representative of God on earth. He was fallible like every other Muslim and subjects to the same impersonal authority of Divine Law.

4. Although the Caliph was the head of the State, he could be directly sued in an ordinary law court.

5. The Caliph could indicate his successor, but the nomination was not valid without the confirmation by the people.

6. The elector had the right to demand the deposition of the Caliph, or the dismissal of his officials if their behavior was in contravention to the laws of the sharia (Hassan P. F., 1970).

About the ijtihad and parliament Iqbal writes in his book Reconstruction of Religious Thought in Islam, that the growth of republican spirit and the gradual formation of legislative assemblies in Muslim lands constitute a great step forward. The transfer of power of ijtihad from individual representatives of schools to a Muslim legislative assembly, which in view of the growth of opposition sects, is the only form ijma can take in modern times, will secure contributions to legal discussions from laymen who happen to possess a keen insight into affairs (Malik N. S., 1998).

Dr Waheed Ishrat says that Iqbal favoured 'elected assembly' and its mandate to have 'power of ijtihad' instead a single individual for interpretation of sharia. Even he liked that 'elected body' functions on the line of a true caliphate system, and the legislature can make a 'collective decisions' as legislated collectively. So, he favored such system, as Turkey made it operative at that time, where Muslims are in majority (Quershi, 1977). Anyhow, Iqbal, as such, was least concerned with the name of the system of the government but most concerned with the 'principles of spiritual' of Islam to be its permanent features.

As Iqbal grew older and Indian became assertive in their demand in political arena-his thought became solid and mature, and so he was dictated by the political condition of subcontinent to do something practically if he were to realize these ideals of politics in the larger interest of the Muslim ummah. He enters practical politics in 1926. He complemented his pan-Islamism with territorial nationalism in the subcontinent context. "After elaborating the basic postulates of Islamic ideology and its relevance to individual, society, and mankind, turned his attention to the Indian Muslims who were simultaneously menaced by British Imperialism and danger of permanent Hindu domination. Caught in the vortex of Indian politics, therefore, the basic problem of the Indian Muslims was how to regenerate their individual and collective selves and preserve their Islamic identity. A satisfactory solution of the problem implied policies and actions at three different levels:

1. Reconstruction of Muslim society in the Indian subcontinent according to the Islamic ideology.

2. Facing the upsurge of Indian nationalism to preserve the Islamic identity of Indian Muslims.

3. Integration of the Indian Muslims with the rest of the Islamic Millat" (Aziz, 1987).

Iqbal considered Muslim community as a separate nationality, and he wanted first, full autonomous status in the Muslim majority areas, and later an independent action of line from the Congress. His presidential address of 1930 is famous in this regard: I would like to see the 
Punjab, North-West Frontier Province, Sind, and Baluchistan amalgamated into a single state. Self-government, within the British empire or without the British empire, the formation of a consolidated Indian Muslim state appears to me the final destiny of Muslim at least of North-West India (Quershi, 1977).

However, for Iqbal the establishment of a Muslim State in the Indian subcontinent was not an end by itself, but it was a means to achieve a higher goal-consolidation of the world-millat. Thus, the contradiction between Iqbal's theory of the Islami millat and his proposal for the establishment of a consolidated Muslim State in the North-West Indian region was, in fact more apparent than real... Hindu-Muslim conflict was a much deeper ideological cleavages between Islam and nationalism, and 'therefore, the construction of a polity on national lines, if it means a displacement of the Islamic principle of a solidarity, is unthinkable to a Muslim" (Quershi, 1977). "The Indian Muslims, by virtue of a common faith and history, are closely bound together with the rest of the Islamic millat living in the West Asia, and at the same time have their peculiarly Indian features. Therefore, in lending support to Two- Nation theory, Iqbal was chiefly concerned with the consolidation of the Muslim community in the Northwest Indian region where they constituted majority. For this purpose, he used the theory of modern nationalism to counter the arguments of the All-Indian National Congress in defence of united Indian nationalism" (Quershi, 1977). Iqbal believes ideally in a completely unified Muslim world.

\section{CONCLUSION}

Allama Iqbal political thought is as much relevant in the today world because he calls for the reformation of Muslims mind in all time in first place and second his philosophy gains universal dimension, particularly for Islamic world that is experiencing dissolution and alienation in every field (Razak, 2011) (Hamit, 2020). Today Muslim world need the emancipator vision of Iqbal that has embraced Western culture, political system, and economic order; and Islam is no more a guiding principle in public or private or in state and society life (Naeem, 2014). Work culture is absent largely, materialism is worshipped, Muslim unity at global level is in shattered, ijtihad is not practiced, self-esteem of Muslim community is dented at international level, Muslim countries are less democratic, and individual and society/state do not see eye to eye on fundamentals of politics as Iqbal had wished. It is a proper time to bring into use his political philosophy of tauhid, khudi, momin, millat, spiritual democracy, etc. To take a new start on these lines to unite Muslim around the world and create a universal order based on the Quranic principles of tauhid, solidarity, equality, brotherhood to deliver freedom to the world at large from unjust politico-economic order and free Muslim masses from their own unjust rulers. Such an order shall be first created in an individual Muslim state and then shall be ideologically integrated to make one whole of universal Muslim world that would promote humanism as Islam teaches and Iqbal likes.

\section{Acknowledgement}

The authors acknowledge Dr. Hanif-ur-Rehman (Late) for the kind help in checking and refinement of the early drafts of this paper.

\section{REFERENCE}

Aziz, K. (1987). A History of the Idea of Pakistan. Lahore : Vanguard Book Ltd.

Ahmad, D. M. (1995). Iqbal's theory of Muslim community and Islamic universalism. In D. W. Qureshi, Iqbal Review. Lahore: Iqbal Academy Pakistan.

Ahmad, D. M. (1995). Iqbal's theory of muslim community and islamic universalism. In D. W.

Qureshi, Iqbal Review. Lahore: Iqbal Academy Pakistan.

Aziz, K. (1987). A History of the Idea of Pakistan. Lahore : Vanguard Book Ltd.

Dani, A. H. (1977). Iqbal's Views on Nation and Millat. Iqbal Centenary Papers, 1, 157-191.

Dino, A., Siraj Ahmed, \& Jalil Ahmed. (2018). Dr. Allama Iqbal and Division of Sub-continent.

Journal of the Punjab University Historical Society, 11-19.

Faruqi, K. (1979). Iqbal- The Humanist . Indian Literature , 97-107.

Hamit, D. (2020, 11 9). Muhammad Iqbal: 'Greatest intellectual of Islamic culture'. Anadolu Agency. Hassan, D. R. (2008, 8 14). Understanding Iqbal's “dream” of Pakistan. The Nation. 
Hassan, P. F. (1970). The Political Philosophy of Iqbal. Lahore: Publishers United Ltd.

Iqbal, M. (2010). Ramuz-e-Bekhudi. (A. R. Rafiqee, Ed.) Lahore: Iqbal Academy Pakistan. Iqbal, M. (2018). Bang e Dara. Amazon: CreateSpace Independent Publishing Platform.

Khattak, Y. (1998). Iqbal's Journey to Pakistan. In N. S. Malik, The Political Sagacity of Iqbal (pp. 109-116). Lahore: National Book Foundation.

Maitre, L.-C. (1963). Introduction to the Thought of Iqbal. Lahore: Iqbal Academy.

Malik, H. (1971). Iqbal: Poet-philosopher of Pakistan. New York: Columbia University Press. Malik, N. S. (1998). The Political Sagacity of Iqbal. Islamabad: National Book Foundation.

Naeem, R. (2014, 11 9). REVIEW: Iqbal: The Life of a Poet, Philosopher and Politician. DAWN.

Parray, F. A. (2013). Zarb-i-Kaleem, SOCIO-POLITICAL THOUGHT OF IQBAL With special reference to Zarb-i-Kaleem. M.Phil Dissertation. Srinagar: Iqbal Institute of Culture \& Philosophy, University of Kashmir.

Pay, S. (2015). The Support for the Caliphate from Indian Subcontinent to Anatolia and Muhammad Iqbal. International Journal of Humanities and Social Science, 149-155.

Qazi, U. (2013). Iqbal's Urdu Political Poems: The Writer Against Colonialism by Uzma Qazi. PhD Dissertation. University of Alberta.

Quershi, W. (1977). Selection from Iqbal Review. Lahore: Iqbal Academy.

Razak, M. A. (2011). Iqbal's Ideas for the Restoration of Muslim Dynamism. Journal of Islam in Asia, 377-402.

Sheikh, M. S. (1989). Allama Muhammad Iqbal: The Reconstruction of Religious Thought in Islam . Lahore: Institute of Islamic Culture.

Sherwani, L. A. (1977). Speeches, Writings and Statements of Iqbal. Lahore: Iqbal Academy. 